\title{
ADMINISTRATION AND ENFORCEMENT UNDER THE UNIFORM CONSUMER CREDIT CODE
}

\author{
Barbara A. Curran*
}

\section{INTRODUCTION}

Compliance with the Uniform Consumer Credit Code (UCCC) must be enforced if the protections afforded consumers under its provisions are to be meaningful. Individual consumer remedies, in and of themselves, cannot be expected to assure general compliance with the Code on the part of those creditors who are intent on engaging in sharp and unlawful practices. The intrinsic limitation in consumer remedies in this respect is that they are individual in nature and remedial in effect. Consequently, claims for redress asserted by individual consumers can be expected to have only a limited deterrent effect on continuance of conduct that does not conform to the spirit and letter of the UCCC. For this reason, the designation of a state official with responsibility to monitor the making and enforcement of credit transactions generally and the power to restrain activities that violate the UCCC is significant.

The primary task of the Administrator under the UCCC is that of assuring that the conduct and practices of participants in the market comply with the provisions of the Code. Because the UCCC is largely self-implementing, the Administrator's rule-making responsibilities are limited. Supervisory tasks usually associated with implementation of licensing provisions are also limited. Instead, emphasis is placed on his role as educator, coordinator, watch-dog, investigator, and enforcer of compliance. He is responsible for investigating violations and complaints of violations and is provided with appropriate powers to deal with incidents of noncompliance and prevent further violations from occurring. By limiting mandatory administrative activities that essentially implement the provisions of the Code, e.g., licensing and rule making, or are clerical, e.g., record keeping or receiving reports, the drafters have allowed the Administrator to commit his resources and energies to assuring that conduct in the consumer credit market place conforms to the objectives and purposes of the Code.

\section{I}

\section{Administration}

Designation of the Administrator under the UCCC is left to individual state legislatures. ${ }^{1}$ The drafters state a strong preference for conferring all administrative

* B.A. 1950, University of Massachusetts; LL.B. I953, University of Connecticur; LL.M. I96r, Yale University. Research Attorney, American Bar Foundation. Author, Trends in Consumer Credit LegisLATION (1965).

${ }^{2}$ UnIform Consumer CRedit CODE $\$ 6.103$ [hereinafter cited as UCCC]. On the text of the UCCC, see Foreword, in this symposium, p. 639 n.r. 
powers and responsibilities on one agency. It is recognized, however, that this may not be possible under existing constitutional provisions in some states, and that, consequently, it may be necessary for administration to be shared by two or more agencies or departments. For the latter case, the drafters recommend the creation of a Commission as the officially designated Administrator. Members of the Commission would be the agencies sharing responsibility for administration. The statute, or the Commission itself, would then allocate the administrative responsibilities under the Code among member agencies. ${ }^{2}$

The drafters are correct in urging centralization of administrative powers in one agency. One of the most serious deficiencies in existing consumer credit legislation is lack of uniformity in regulation and consistency in enforcement. The very essence of the integrated approach to consumer credit regulation adopted by the UCCC is uniformity in regulation of all consumer credit transactions, where practicable. It follows that implementation of the administrative provisions of the Code should be under the direction and control of one central administrative authority that establishes policies and procedures consistent with the over-all objectives of the UCCC.

The drafters have, however, made some exceptions to centralization of authority. Quite appropriately, the Commissioner of Insurance is assigned rule-making and some enforcement powers in respect to premium rates and insurance forms for credit insurance. $^{3}$ In this case, it is the Insurance Commissioner that is the expert in a particular aspect of consumer credit transactions. In addition, the Administrator shares administration with the state or federal agency or department supervising financial institutions such as banks, savings and loan associations, and credit unions. ${ }^{4}$ The nature of the shared administration is discussed more fully in the following sections on rule making and enforcement. Simply stated, the power of the Administrator to take action in certain cases is pre-empted by the supervisor of the designated financial institutions. In spite of provisions for cooperation and collaboration, there is no doubt that the benefit to be gained from centralization of administration under the UCCC is diluted. The technical jurisdictional difficulties may well have been impossible for the drafters to overcome. Nevertheless, it is unfortunate that the drafters did not, or could not, confer the entire responsibility for implementation and enforcement of the UCCC on a single agency whose primary concern and expertise would be consumer credit transactions.

Effective administration of the Code is, of course, dependent on adequate financing of the Administrator's operation, which, regardless of economies implicit in centralization of administration, will be expensive. The powers and dedication of the Administrator come to naught if he lacks the economic resources to acquire necessary staff and supporting services. Adequate financing can mean the difference between

\footnotetext{
${ }^{2}$ UCCC $\S 6.103$, Comment.

${ }^{3}$ UCCC $\$ \$ 4.107$, .I08, .IIr, I.Ir2. See Davis et al., The Regulation of Consumer Credit Insurance, in this symposium, p. $7 \mathrm{r} 8$.

'UCCC \$ 6.105.
} 
an essentially clerical administration and an administration that implements and enforces policy. Fees paid by licensees and registrants under the UCCC are not intended to finance the Administrator's office. Instead, financing is to come out of general appropriations. ${ }^{5}$

The nomination of the Administrator is, of course, crucial. Assuming adequate financing, he has the power to acquire the kind of staff that permits him to be an energetic and creative force in the application of the UCCC. A sensitive, knowledgeable, politically astute, and dedicated Administrator can maximize his powers to protect the public as well as the interests of lawful and conscientious creditors concerned about a viable market. On the other hand, the Administrator's office may limit itself to performing the mandatory tasks assigned under the UCCC.

II

\section{LiCENSING AND REgISTRATION}

Persons engaging in the business of making, or taking assignments of, supervised loans must obtain a license from the Administrator. ${ }^{6}$ Supervised loans are loans the finance charge for which exceeds an effective annual rate of eighteen per cent. ${ }^{7}$ Any financial institution authorized to take deposits and make loans is exempt from this licensing requirement if the general business operation of the institution is supervised by any other state or federal agency. ${ }^{8}$ Banks, savings and loan associations, and credit unions would generally come within this exemption.

Application for a license is made to the Administrator on forms specified by and in accordance with procedures established by him. The Administrator may refuse to issue a license only if he finds that the financial responsibility, character and fitness of the applicant are not "such as to warrant the belief that the business [of the applicant] will be operated honestly and fairly within the purposes of [the] Act." A creditor, otherwise required to obtain a license to make supervised loans, is automatically licensed under the UCCC if, immediately prior to the effective date of the UCCC, he holds a license to make loans under a licensed lender act, such as a small loan law, that is repealed by the enactment of the UCCC. ${ }^{10}$

A creditor, whether or not located within the state, need obtain only one license to engage in the business of making supervised loans within that state or to take assignments of such loans. Moreover, a license remains in force, without renewal, until the licensee relinquishes the license voluntarily or until the Administrator suspends or revokes the license." A license may be revoked, only after hearing, if

\footnotetext{
${ }^{\sigma}$ UCCC $\$ 3.502$, Comment.

' UCCC $\$ 3.502$. In the case of assignments, assignees who do not take assignment for purposes of collection need not be licensed.

${ }^{7}$ UCCC $\$ 3.501(3)$.

${ }^{8}$ UCCC $\$ \$ 3.502,1.301(17)$.

- UCCC $\$ 3.503$.

${ }^{10}$ UCCC $\$ 9.102$.

${ }^{11}$ UCCC $\$ 3.502$, Comment; UCCC $\$ \$ 3.504(1)$, (5).
} 
the licensee has "repeatedly and willfully violated" the UCCC or facts exist that would justify the Administrator in refusing to issue a license initially. ${ }^{12}$ A license may be suspended for a maximum of thirty days if the Administrator finds probable cause for revocation exists. ${ }^{13}$ The Administrator may, of course, terminate suspension or reinstate a revoked license at any time if the facts indicate that the creditor is then in compliance with the requirements of the UCCC. ${ }^{14}$

A licensed lender is required to file annual reports in the form prescribed by the Administrator. ${ }^{15}$ In addition, the Administrator must examine the books and records of each licensee periodically. If books and records are not located within the state, the licensee must make them available for examination in the state or reimburse the Administrator for sending a representative to examine the books and records where located. ${ }^{16}$

Although only certain creditors making, or taking assignments of, supervised loans are required to be licensed, all licensees, all persons or organizations extending consumer credit within the state, and all persons and organizations with offices within the state who take assignments of consumer credit obligations, whether or not the credit is a loan or sales credit, are required to register with the Administrator within thirty days after commencing business and thereafter annually. ${ }^{17}$ The information to be furnished to the Administrator at each registration includes

(I) name of registrant;

(2) name under which business is transacted;

(3) principal office;

(4) all offices within state;

(5) if credit is not extended at an office, how the credit extension is transacted;

(6) agent designated for service of process;

(7) whether registrant makes loans and, if so, whether they are supervised loans. ${ }^{18}$

Each registrant is required to pay a minimum annual fee of ten dollars, plus an additional amount computed at the rate of ten dollars per $\$ 100,000$ of credit extended or purchased by way of assignment during the preceding year. ${ }^{10}$ In calculating the fee due, a registrant need not include the amount due on any contract if the assignor included that contract in the calculation of his registration fee. As indicated above, these fees are not intended to finance the Administrator's operation.

The licensing and registration provisions of the UCCC are undoubtedly a substantial improvement over existing consumer credit legislation. Under licensing

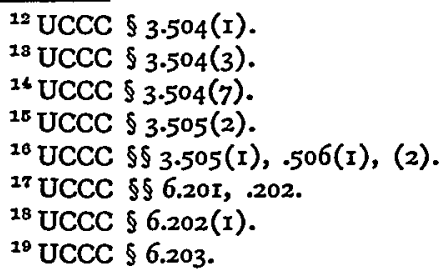


provisions in present licensed lender laws, most notably small loan and consumer finance laws, licensed lenders are afforded exclusive access to certain segments of the market. Unlicensed lenders may not make loans at the high rates permitted under these laws and, consequently, are unable to compete for the business of the higher risk borrower generally serviced by the licensed small loan lender. The monopolistic character of the small loan market can be attributed to the operation of the licensing requirements of these laws. In addition to qualifications not unlike those established in the UCCC, most small loan laws require that a license be obtained for each office. A small loan license will not be issued by the supervising agency unless it appears that the opening of a new office suits the convenience and advantage of the community or neighborhood to be served. In most cases, the application of this convenience and advantage test has substantially restricted entry of new lenders into areas in which a licensed lender is already located. The drafters of the UCCC have eliminated the convenience and advantage test in the interest of fostering open access to the entire market by competing creditors.

The licensing provisions of the UCCC establish qualifications that any reputable lender can meet. Moreover, deterrents in the form of license fees and applications for annual renewal of licenses have been eliminated. On the other hand, the licensed lender must file annual reports relating to his credit operations. Although the reports may be set forth in a form that masks the details of the licensee's business from his competitors, preparation and submission of these reports is an additional cost of business for the licensee that the unlicensed creditor does not incur. Moreover, although the drafters have simplified the licensing provisions of the UCCC, a portion of the financial resources of the Administrator's office must be allocated to processing license applications, supervising filing of annual reports, and carrying out periodic examinations of licensees required under the UCCC.

The registration requirement in the UCCC gives the Administrator ready access to information as to the identity of all participants in the market and the character of their credit activities. This information presumably facilitates fulfillment of the enforcement responsibilities of the Administrator. Present consumer credit legislation, with some exceptions, does not require registration or licensing of persons or organizations engaging in the extension of sales credit, and, in this respect, the registration requirements of the UCCC represent an improvement. However, if registration of market participants is adequate to enable the Administrator to supervise, investigate, and enforce compliance with the UCCC, the requirement of licensing for certain participants is, at a minimum, a dubious additional cost both to licensees and the Administrator. ${ }^{20}$ If registration is not adequate, then all participants should be subject to licensing requirements. As noted elsewhere, the UCCC is essentially self-executing, and the primary responsibility of the Administrator is ferreting out and pursuing persons violating its provisions. Experience indicates

\footnotetext{
${ }^{20}$ See UCCC $\$ 3.5 \mathrm{I} 3$.
} 
that abuses are no less likely to occur in extensions and collections of sales credit than with lender credit. In this instance, the drafters, perhaps bowing to what they viewed as political necessity, have not been consistent with their own policies by establishing, in this instance, differential treatment of participants in the credit market.

\section{III}

\section{Rule Making}

The rule-making powers of the Administrator are limited for the most part to establishing procedures and authorizing forms used in connection with the administration of the licensing and registration provisions. Subject to the exceptions noted below, provisions relating to substantive matters, such as maximum rates and prohibited activities, do not require administrative action for their implementation.

The Administrator is empowered to make rules relating to ( $\mathrm{I}$ ) cost of living adjustments provided for in the UCCC and (2) methods for arriving at disclosure rates. In neither case, however, will the failure of the Administrator to promulgate rules prevent implementation of the UCCC provision. In the first case, all dollar amounts specified in the UCCC are automatically increased as of the July I of any even numbered year if the Consumer Price Index for the preceding year has increased over the 1967 Index by ten per cent or more since the most recent preceding adjustment. ${ }^{21}$ The Administrator is required to issue a ruling prior to the April I preceding any such change announcing dollar changes to be effective on the following July $\mathrm{x} .{ }^{22}$ However, any creditor may calculate adjustments himself in accordance with the method of computation spelled out in the UCCC, or he may rely on the latest ruling of the Administrator. ${ }^{23}$

As to the second case, all interest and finance charges must be disclosed to consumers in the form of effective annual percentage rates calculated in accordance with the methods set forth in the UCCC. ${ }^{24}$ The Administrator is, however, authorized to establish by rule an alternate method for computing disclosure rates if the method authorized "materially simplifies computation while retaining reasonable accuracy as compared with" the method spelled out in the UCCC. ${ }^{25}$ The Administrator may also authorize the use of tables or charts by creditors for calculating disclosure rates, provided that the amount by which the rates derived from these tables or charts deviate by no more than eight per cent from the rate when calculated in accordance with the method prescribed in the UCCC. ${ }^{20}$

\footnotetext{
${ }^{21}$ UCCC $\S \S \operatorname{I.106(I)-(3),~(6).~}$

22 UCCC $\$ 1.106(4)$.

${ }^{23}$ UCCC $\$ 1.106(5)$. If the Index increased and the Administrator did not make a new ruling, the creditor could use the Administrator's latest ruling. Under the UCCC, dollar amounts may not be reduced below amounts set forth in the UCCC on date of enactment. UCCC $\$$ x.ro6(2)(c).

${ }^{24}$ UCCC $\$ \$ 2.304(2), 3.304(2)$.

${ }^{20} \mathrm{UCCC} \$ \$ 2.304(2), 3.304(2)$.

${ }^{20}$ UCCC $\$ \$ 2.304(5)(b), 3.304$ (5) (b).
} 
One provision requiring interpretative action by the Administrator for implementation relates to permissible additional finance charges, i.e., charges that are not subject to ceilings imposed on interest or finance charges. Three types of additional charges are permitted under the UCCC: (I) official fees and taxes; (2) charges for authorized insurance; (3) in the case of certain credit cards, annual charges for the privilege of using the card, and (4) charges for other benefits, including insurance, conferred on the debtor, if the benefits are of value to him and if the charges are reasonable in relation to the benefits, are of a type which is not for credit, and are excluded as permissible additional charges from the loan finance charge by rule adopted by the administrator. ${ }^{27}$ In the case of item (4), the Administrator's determination that a charge qualifies as a permissible additional charge is a crucial element if the charge is not to be treated as a part of the finance charge or interest and therefore subject to the rate maximum imposed by the UCCC. On the other hand, the charge will not qualify if it does not meet the other tests in item (4), any rule by the Administrator to the contrary notwithstanding. It would seem, however, that the creditor who treats a charge as permissible in reliance on a ruling by the Administrator is protected from any liability, except for refunding the excess charge, if the Administrator's ruling is thereafter determined to be invalid. ${ }^{2 s}$

The other provision requiring action by the Administrator for its implementation relates to the debtor's right to rescind a credit arrangement secured by an interest in residential real estate other than a first lien taken for credit extended for purchase of the property. ${ }^{29}$ The Administrator must establish rules for apprising the debtor of his right to rescind and the manner in which he may exercise this right. In addition, the Administrator has power to authorize and establish rules under which the rights provided for the debtor under this section may be waived or modified. Although waiver may be permitted only "if [the Administrator] finds that the action is necessary in order to permit homeowners to meet bona fide personal financial emergencies," ${ }^{30}$ a liberal interpretation of this provision by the Administrator could lead to abuses.

Rule-making power as to insurance provisions of the UCCC rests primarily with the Commissioner of Insurance rather than the Administrator. A creditor may not make a charge for insurance in excess of that paid to the insurer and permitted by the schedule of premium rates filed by the insurer with the Commissioner of Insurance, when such filings are required. ${ }^{31}$ In addition, refunds of charges for insurance must be "appropriate" in amount. ${ }^{32}$ A refund is appropriate if computed

\footnotetext{
${ }^{27}$ UCCC $\$ 3.202$ (I) (emphasis added). The comparable provision in the article on sales credit is UCCC $\S 2.202(\mathrm{x})$.

${ }^{28}$ UCCC $\$ 6.104(4)$.

${ }^{20}$ UCCC $\$ 5.204$.

${ }^{30}$ UCCC $\$ 5.204(4)$.

${ }^{81}$ UCCC $\S 4.107(x)$.

${ }^{30} \mathrm{UCCC}$ \& 4.108(3).
} 
in accordance with a method prescribed or approved by the Commissioner of Insurance or filed by the insurer with the Commissioner of Insurance. ${ }^{33}$ All insurance forms and schedules of rates used in connection with credit life or accident and health insurance must be filed by the insurer with the Commissioner of Insurance. ${ }^{34}$ No creditor may use any rate schedule or insurance form that has been disapproved by the Commissioner of Insurance. ${ }^{35}$

Although the Commissioner of Insurance has responsibility for acting on rates, refunds, and forms, he is primarily responsible for regulating the activities of insurers selling credit insurance. ${ }^{36}$ The Administrator is not authorized to proceed against an insurer who has not complied with insurance regulations but is required to advise the Commissioner of Insurance of violations by insurers that come to his attention. ${ }^{37}$ On the other hand, the creditor using insurance charges or forms not approved by the Commissioner of Insurance is subject to the jurisdiction of the Administrator. The UCCC instructs the Administrator and Commissioner of Insurance to collaborate in maintaining compliance with the insurance provisions of the UCCC, and they are authorized to act jointly in any case where either is otherwise empowered to act alone. ${ }^{38}$

\section{IV}

\section{ENFORCEMENT}

The Administrator has substantial powers for enforcing compliance with the UCCC. Coupled with expanded individual consumer remedies under the Code, the potential for effective enforcement is greater than that afforded under existing legislation in most states. The crucial questions are, however, whether consumers will take advantage of remedies available to them and whether the Administrator will effectively utilize his powers.

\section{A. Investigatory Powers}

The Administrator is required to make periodic examinations of the business, loans, and records of all licensees. The frequency of such examinations is left to the determination of the Administrator. In addition, he may, at any time, investigate the business, loans, and records of any licensee for the purpose of discovering violations of the UCCC and of any other lender making loans at an effective rate of annual interest in excess of ten per cent. ${ }^{30}$ If the Administrator has "probable cause to believe" that any person or organization has violated the UCCC, he may make an investigation to determine if, in fact, the act or conduct in question has

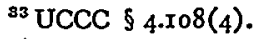

${ }^{34} \mathrm{UCCC} \$ 4.203(2)$.

${ }^{85} \mathrm{UCCC} \$ 4.203(\mathrm{I})$.

${ }^{36} \mathrm{UCCC} \$ 4 . \mathrm{II} 2(\mathrm{I})$.

${ }^{37} \mathrm{UCCC} \S 4 . \mathrm{III}$.

${ }^{88} \mathrm{UCCC} \$ 4 . \mathrm{IrI}$.

${ }^{39}$ UCCC $\$ \$ 3.506(I), .501(1)$, (2).
} 
taken place. ${ }^{40}$ Technically at least, investigations not based on complaint or prior information sufficient to constitute "probable cause" are not authorized except as to lenders. Mandatory periodic examinations of licensees may bring to light possible violations. It seems unlikely, however, that the Administrator will otherwise commit limited resources to fishing expeditions aimed at discovering violations committed by lenders without some prior indication that violations are probably occurring. That being the case in most circumstances, the Administrator's inquiry into activities of lenders could be conducted just as readily under the authority of the provisions permitting investigations for probable cause. If, indeed, this is not the case, then the question-similar to that previously raised in the context of licensing requirements-is why there should be a different standard for investigation of the activities of persons extending sales credit than for persons making loans. ${ }^{41}$

The Administrator is authorized to take testimony under oath, subpoena witnesses, and otherwise compel production of materials relevant to the purposes of his examination or investigation. Books or records located outside the state must be produced within the state or expenses paid for the Administrator's representative to examine them, wherever located. The Administrator may apply to the appropriate court for an order compelling appearance of witnesses or production of evidence. ${ }^{42}$

\section{B. Administrative Orders}

The Administrator may issue a cease and desist order to any creditor violating the UCCC. ${ }^{43}$ Unlike the Administrator's investigatory powers, which apply to any person violating the Code, an Administrator's order may only be directed to a creditor or his representative. The order, which may be issued only after proper notice and hearing, is subject to judicial review if the creditor initiates review by petition to the appropriate court within thirty days after he receives a copy of the order. ${ }^{44}$ In the absence of a timely petition for review by the creditor, the Administrator may obtain judicial enforcement of his order merely by showing that the order was issued, that no petition for review was made within the time period allowed, and that the creditor was subject to the jurisdiction of the Administrator. ${ }^{45}$ Only if the creditor requests judicial review will the court review the findings and record on which the order was based. After review, the court may enforce

\footnotetext{
${ }^{10} \mathrm{UCCC} \S \S 6.106(\mathrm{x}):$

"If the Administrator has probable cause to believe that a person has engaged in an act which is subject to action by the Administrator, he may make an investigation to determine whether the act has been committed ...."

${ }^{11}$ UCCC $\$ \$ 3.506,6.106$.

"2 UCCC $\$ \$ 6.106(\mathrm{x})$-(3).

${ }^{4}$ UCCC $\$ 6.108(\mathrm{r})$.

"UCCC $\$ 6.108(2)$.

"UCCC \$ 6.I08(5).
} 
the order, reverse or modify it, or remand the case to the Administrator with appropriate instructions. ${ }^{46}$

C. Civil Actions by the Administrator

In addition to the power to request a court to enforce administrative orders, the Administrator is authorized to bring the following civil actions:

(I) action to restrain any person from violating the UCCC; 47

(2) action to restrain a creditor or his representative from making unconscionable agreements or engaging in unconscionable or fraudulent conduct; ${ }^{48}$

(3) action to recover excess charges and associated civil penalties on behalf of one or more debtors; ${ }^{49}$ and

(4) action to recover civil penalties for willful violations of the UCCC by a creditor or his representative. ${ }^{50}$

The authority to seek a judicial restraining order is an extension of the Administrator's power to issue a judicially enforceable administrative cease and desist order to creditors. The court order that may be requested by the Administrator under this provision is, however, broader in application and scope than the Administrator's own order. The court order, like the Administrator's investigation of violations, may be directed to any person or organization violating the UCCC and not just to creditors or their representatives. Moreover, the Administrator may request, and the court may grant, an order not only restraining violations but also providing other appropriate relief. 51

A court may refuse to enforce, or limit the application of, any agreement that it finds, as a matter of law, to have been unconscionable at the time the agreement was made..$^{52}$ This consumer remedy, similar to the unconscionability provision in the Uniform Commercial Code, ${ }^{53}$ is individuated in application and primarily remedial in effect. Although the Administrator is expressly prohibited from issuing administrative orders dealing with unconscionable or fraudulent conduct or unconscionable contracts, ${ }^{54}$ the drafters of the UCCC have expanded measures for controlling unconscionable practices by creditors by authorizing the Administrator to bring civil actions to restrain creditors from engaging in unconscionable and fraudulent conduct including the making and enforcing of unconscionable agreements. ${ }^{55}$

\footnotetext{
${ }^{48}$ UCCC $\$ 6.108(2)-(4)$.

${ }^{47} \mathrm{UCCC} \S 6 . x \mathrm{x}$.

${ }^{48} \mathrm{UCCC} \$ 6 . \operatorname{III}(\mathrm{I})$.

so UCCC $\$ 6.113(\mathrm{I})$.

${ }^{50} \mathrm{UCCC} \S 6 . \mathrm{Ir}_{3}(2)$.

${ }^{51}$ UCCC $\$ 6.110$.

${ }^{52}$ UCCC $\$ 5.108$.

${ }^{23}$ Compare UCCC $\$ 5.108$ with Uniform CoMamercial COdE $\$ 2-302$.

s4 UCCC $\$ 6.108(6)$.

${ }^{8}$ UCCC $\S 6.11 r$.
} 
A court may, upon petition by the Administrator, restrain a creditor from making or enforcing contracts with unconscionable terms or from using unconscionable or fraudulent practices (I) to induce consumers to undertake consumer obligations or (2) to enforce consumer agreements. ${ }^{56}$ A court order issued pursuant to this provision is remedial to the extent it restrains enforcement of unconscionable contract terms. It is broader in application than the individual remedy because the restraining order may apply to multiple consumer agreements held by a single creditor. In other respects, the provision is preventive in effect.

The stated intent of the drafters is to make the UCCC responsive to the need for ongoing protection against unforeseen or unforeseeable practices that, from time to time and under certain circumstances, are unconscionable or fraudulent. ${ }^{57}$ In effect, the Administrator is called upon to request the courts to give operational meaning to these concepts. How significant this provision may be in providing protection to consumers against the techniques of unscrupulous creditors depends, first, upon the aggressiveness of the Administrator in bringing cases to the courts' attention and, second, upon the interpretations made by the courts in applying these concepts.

A general framework for applying this provision is set forth in the UCCC. Relief may be granted only if the court finds that the unconscionable contracts or unconscionable or fraudulent conduct of the creditor have or are likely to injure consumers. Moreover, the injury must occur because the transactions involved are credit transactions. ${ }^{58}$ The drafters have specified five factors that "among others" are to be considered by the court, and presumably by the Administrator in deciding to initiate action:

(r) no expectation on the part of the creditor at the time the agreement was made that payment in full could be made;

(2) knowledge by a seller or lessor that the debtor would not receive substantial benefit from the goods or services sold or leased;

(3) gross disparity between the sale price of goods or services and the going market price;

(4) separate charges for insurance such as to make the entire agreement unconscionable;

(5) the creditor's knowing exploitation of the debtor's "physical or mental infirmities, ignorance, illiteracy or inability to understand the language of the agreement, or similar factors." ${ }^{.99}$

It is to be noted that a charge or practice expressly permitted by the UCCC is not unconscionable in and of itself. ${ }^{00}$

\footnotetext{
${ }^{\circ 0} \mathrm{UCCC} \S 6 . \mathrm{III}(\mathrm{I})$.

${ }^{87}$ UCCC $\$ 6.1 \mathrm{Ir}$, Comment.

${ }^{58}$ UCCC $\$ 6 . \operatorname{Irr}(2)$.

${ }^{\circ}$ UCCC $\$ 6 . \operatorname{III}(3)$.

${ }^{\circ 0}$ UCCC $\S 6.1 I I(4)$.
} 
The Administrator is also authorized to bring an action on behalf of one or more debtors against any creditor to recover excess charges. ${ }^{B 1}$ This provision is an extension of the remedy for excess charges available to individual consumers. The remedy is the same in both cases, i.e., refund of excess charges and, if the action of the creditor is a willful violation or if he refuses to refund excess charges upon demand, the payment of a civil penalty by the creditor to the debtor in an amount not to exceed the greater of the finance charge or ten times the amount of the excess charge. ${ }^{62}$ The action of the Administrator on behalf of any debtor is stayed if the debtor brings an action for recovery of excess charges himself and will be dismissed if judgment is rendered in the debtor's action. Time limits on actions brought by the Administrator are the same as those specified for individual consumer actions. The effect of this provision may be compared to a class action in the sense that the claims of a group of debtors against one creditor arising out of the same type of injury are adjudicated in the same action. It raises the question as to why the drafters did not also specifically permit consumers to join in this action without requiring the participation of the Administrator or why the power granted the Administrator by this provision and the provision relating to unconscionable and fraudulent conduct was not extended to other violations.

Finally, the Administrator is authorized to bring a civil action against a creditor or his representative to recover civil penalties up to $\$ 5000$ for repeated and willful violations of the UCCC. ${ }^{63}$ An action may not be brought under this section for making unconscionable agreements or engaging in fraudulent or unconscionable activities. The Administrator may, in the course of the performance of his duties, uncover activities that are also subject to criminal penalties under the Code. Presumably the Administrator would bring these to the attention of the state's attorney or other appropriate official authorized to institute criminal proceedings. Criminal penalties are provided for making supervised loans without a license, excessive charges by a licensee, failure to register or pay registration fees, and willful violation of disclosure provisions. $^{\text {et }}$

\section{Restriction on Jurisdiction of the Administrator}

The Administrator is not authorized to investigate the activities of those financial institutions, authorized by law to take deposits and make loans, that are supervised by another state or federal agency. Nor is the Administrator permitted to issue administrative orders to any such organization. The agency responsible for general supervision of such a financial institution is empowered under the UCCC to carry out these administrative tasks. The Administrator is required to inform the designated supervisory agency of noncompliance by institutions over which the

\footnotetext{
${ }^{61}$ UCCC $\$ 6.113(1)$.

${ }^{82}$ See also UCCC $\$ \$ 5.202(3),(4)$.

${ }^{63}$ UCCC $\$ 6.1 \times 3(2)$.

es UCCC $\$ \$ 5.30 x, .302$.
} 
latter exercises jurisdiction. He himself may request information about supervised financial institutions from the supervisory agency. Both agencies are directed to cooperate with each other in insuring compliance with the UCCC, and they may pursue jointly any course of action that either is authorized to take alone. ${ }^{65}$

\section{E. General}

\section{r. Assurance of Discontinuance}

In any case in which the Administrator is authorized to issue an administrative order or initiate civil proceedings, he may, in lieu of proceeding with the order or commencing action, accept a written statement of "assurance of discontinuance" from the person against whom the Administrator would otherwise have taken action. The statement contains the assurance that the signatory will discontinue engaging in the activity in question. If, however, the violation is resumed or continues thereafter, or the signatory otherwise fails to comply with the terms of the written assurance, the Administrator may proceed against him in the appropriate manner, and the statement itself becomes evidence that the signatory did engage in the conduct to which the statement relates prior to the date the assurance was made. ${ }^{86}$

\section{Administrative Procedures and Judicial Review}

Procedures for promulgating rules, issuing orders, hearings, contested cases, and judicial review of administrative action are governed by the state administrative procedure act $^{67}$ If, however, there is no such act or if the existing act is inadequate, an optional section in the UCCC entitled "Administrative Procedure and Judicial Review" may be included. This section contains appropriate provisions adapted from the Uniform Law Commissioners' Revised Model State Administrative Procedure Act. ${ }^{68}$

\section{$\mathrm{V}$}

Relattonship of UCCC to Federal Consumer Credit Protection Act

Although the UCCC repeals existing state legislation regulating consumer credit $^{69}$ it does not, in and of itself, affect the federal Consumer Credit Protection Act of $x 968$ (CCPA). ${ }^{70}$ The federal act consists of five titles. I. Consumer Credit Cost Disclosure; II. Extortionate Credit Transactions; III. Restriction on Garnishment; IV. National Commission on Consumer Finance; and V. General Provisions. Title I does not affect any state consumer credit regulation except to the extent that

\footnotetext{
${ }^{05} \mathrm{UCCC} \S 6.105$.

${ }^{\circ} \mathrm{UCCC} \$ 6.109$.

${ }^{\circ 7}$ UCCC $\$ 6.107$.

${ }^{88}$ See UCCC $\$ \$ 6.401-.415$.

${ }^{00}$ UCCC $\$ 9.103$.

${ }^{70} 82$ Stat. 146 [hereinafter cited as CCPA].
} 
the state law is inconsistent with the federal act. ${ }^{71}$ The Federal Reserve Board, which is charged with responsibility for promulgating regulations under the CCPA, must exempt

any class of credit transactions within any state [from application of the federal disclosure provisions] if it determines under the law of that State that class of transactions is subject to requirements substantially similar to those imposed under this chapter, and that there is adequate provision for enforcement. ${ }^{72}$

Under this provision, the Board has the power to exempt transactions in any state in which the UCCC is in force. Provisions in the UCCC relating to the matters covered in title I are, by and large, derived from the federal act, doubtless with the purpose of meeting the first test. The UCCC provisions discussed in the previous sections establishing the Administrator's office and conferring enforcement powers on him would also be examined by the Board to determine if the second test was met. In making its decision, the Board would probably evaluate not only the statutory powers and responsibilities assigned to the Administrator but also the amounts actually appropriated for financing the Administrator's operation, the latter being a sine qua non of effective implementation of the administrative enforcement provisions. If the exemption were not granted by the Board, then the provisions of the CCPA would apply even in a UCCC state. Compliance with the federal act would be enforced by the federal agencies designated in the CCPA, with residual enforcement powers resting with the Federal Trade Commission. ${ }^{73}$ It is to be noted that the CCPA does not permit extension of the exemption to regulation of credit advertising.

The CCPA provides that federal regulation of extortionate credit transactions (Title II) does not pre-empt state regulation dealing with the same subject matter. ${ }^{\mathbf{7}}$ In the case of garnishments ('Title III), the Secretary of Labor is authorized, but not required, to exempt "garnishments issued under the laws of any State if he determines that the laws of that State provide restrictions on garnishment which are substantially similar to those provided in [the CCPA]."75 Moreover, Title III provides that the federal garnishment provision does not affect the garnishment laws in any state that provides better protection for the consumer than the CCPA. ${ }^{70}$

On the other side of the coin, the Administrator is required to take into consideration regulations promulgated by the Federal Reserve Board under the CCPA. whenever the Administrator adopts, amends, or repeals any rules under the UCCC. In addition, the Administrator, in his annual report to the governor or the legislature, is required to state the extent to which his rules are "not in harmony" with

\footnotetext{
${ }^{71}$ CCPA $\$$ III.

${ }^{72}$ CCPA 123 (emphasis added).

${ }^{73}$ CCPA $\$$ xo6.

74 CCPA $\$ 202$.

${ }^{75}$ CCPA $\$ 306$.

${ }^{70}$ CCPA $\$ 307$.
} 
